\title{
Long-alkyl-chain-derivatized imidazolium salts and ionic liquid crystals with tailor-made properties $\uparrow$
}

Received 3rd December 2013 Accepted 12th February 2014

DOI: $10.1039 / \mathrm{c} 3 \mathrm{ra} 47250 \mathrm{~g}$

www.rsc.org/advances

\author{
Xinjiao Wang, ${ }^{a}$ Michelle Sternberg, ${ }^{a}$ Florian T. U. Kohler, ${ }^{b}$ Berthold U. Melcher, ${ }^{b}$ \\ Peter Wasserscheid ${ }^{\star b}$ and Karsten Meyer ${ }^{\star a}$
}

\begin{abstract}
A series of new 1,3-dialkylimidazolium salts with the general formula $\left[\mathrm{C}_{n} \mathrm{C}_{n} \mid \mathrm{M}\right][\mathrm{A}]$ (for $n=12 ; \mathrm{A}=\mathrm{PF}_{6}{ }^{-}, \mathrm{OTf}^{-}$, $\mathrm{NTf}_{2}{ }^{-}$; for $n=10,14,16$, and $18 ; \mathrm{A}=\mathrm{BF}_{4}{ }^{-}, \mathrm{ClO}_{4}{ }^{-}$) has been synthesized. The $\left[\mathrm{C}_{12} \mathrm{C}_{12} \mid \mathrm{M}\right][\mathrm{A}]$ salts are ionic liquids at room temperature, whereas all $\left[C_{n} C_{n} \mid \mathrm{M}\right]\left[B F_{4}\right]$ and $\left[C_{n} C_{n} \mid M\right]\left[C l O_{4}\right](n=10,14,16,18)$ salts demonstrate a liquid crystalline phase at elevated temperatures that have a large mesophase window, which varies from 10 to $80{ }^{\circ} \mathrm{C}$ with increasing alkyl chain length. In particular, $\left[C_{10} C_{10} \mid \mathrm{M}\right]\left[B_{4}\right]$ shows liquid crystalline behavior at room temperature and therefore is potentially suitable for application as a pre-organized reaction medium in synthesis and catalysis. Viscosity studies of $\left[\mathrm{C}_{16} \mathrm{C}_{16} \mid \mathrm{M}\right]\left[\mathrm{BF}_{4}\right]$ and the corresponding perchlorate salt demonstrate strong non-Newtonian viscosity behavior for the liquid crystalline state of these ionic liquids.
\end{abstract}

\section{Introduction}

Recently, research interest in ionic liquids (ILs) has been growing rapidly. This is mainly due to their unique properties, such as extremely low vapor pressures, wide liquidus ranges, high electric conductivities, wide electrochemical windows, and excellent tribological properties. These properties provide many possibilities for application as solvents and electrolytes. ${ }^{1}$

Ionic liquid crystals (ILCs) are defined as ionic species, exhibiting a liquid crystalline mesophase in a certain temperature range. ${ }^{2}$ These materials hold great potential for catalytic applications by combining the beneficial properties of both ionic liquids and ionic liquid crystals. ${ }^{3}$ Due to growing scientific interest, numerous thermotropic ionic liquid crystals have been studied in recent years and are summarized in a topical review by Axenov and Laschat. ${ }^{4}$ Amongst reported ILs and ILCs, imidazolium-based salts are some of the most frequently studied examples, due in part to the developed synthetic routes that allow for convenient derivatization.,

Currently, 1-alkyl-3-methylimidazolium and $N, N^{\prime}$-dialkylimidazolium ions are by far the most popular cations for both ILs and ILCs. ${ }^{1,7-9}$ There are also reports on other derivatized imidazolium based cationic motifs, such as hydroxyl ${ }^{10}$ or ester group derivatized alky chains ${ }^{11,12}$ as well as simply protonated

${ }^{a}$ Department of Chemistry and Pharmacy, Inorganic Chemistry, Friedrich-Alexander University of Erlangen-Nürnberg (FAU), Egerlandstraße 1, D-91058 Erlangen, Germany.E-mail: karsten.meyer@fau.de

${ }^{b}$ Department of Chemical and Bioengineering, Reaction Engineering, FriedrichAlexander University of Erlangen-Nürnberg (FAU), Egerlandstraße 3, D-91058 Erlangen, Germany. E-mail: peter.wasserscheid@crt.cbi.uni-erlangen.de

$\dagger$ Electronic supplementary information (ESI) available. See DOI: $10.1039 / \mathrm{c} 3 \mathrm{ra} 47250 \mathrm{~g}$ imidazolium ions, ${ }^{13}$ aryl, ${ }^{14-17}$ amide,${ }^{18,19}$ and vinyl functionalized imidazolium-based ionic liquid crystals. ${ }^{20}$ Recently, some unusual ILs and ILCs with a linear tris(imidazolium) core have been reported. ${ }^{21}$

Although all of these functionalized imidazolium-based ILCs have shown interesting thermal properties, imidazolium-based ILCs comprised of linear, long alkyl chains are of special interest as they tend to form ordered structures with similarly structured olefinic solvents. This presents potential for their application as "pre-organized ionic solvents" in catalysis. ${ }^{2}$ Recently, computer simulations were employed, indicating that chain length has an important effect on the formation of liquid crystalline phases. ${ }^{22}$

Organic transformations, stereochemically controlled by such ordered solvents, are an area of increasing interest and examples of rather "traditional" molecular liquid crystalline materials, such as 1-alkyl-substituted imidazolium salts $\left[\mathrm{C}_{n} \mathrm{H}_{2 n+1} \mathrm{IMH}\right][\mathrm{A}]\left(n=10,12,14 ; \mathrm{A}=\mathrm{Cl}^{-}, \mathrm{BF}_{4}{ }^{-}\right)$, have been applied in Diels-Alder reactions. ${ }^{13}$

We previously reported the synthesis of symmetrically disubstituted imidazolium salts, namely 1,3-didodecylimidazolium tetrafluoroborate $\left[\mathrm{C}_{12} \mathrm{C}_{12} \mathrm{IM}\right]\left[\mathrm{BF}_{4}\right]$ and the corresponding perchlorate salt $\left[\mathrm{C}_{12} \mathrm{C}_{12} \mathrm{IM}\right]\left[\mathrm{ClO}_{4}\right]$. Both ILs show thermotropic liquid crystalline behavior over an extended temperature range from $50{ }^{\circ} \mathrm{C}$ to $70{ }^{\circ} \mathrm{C}$ and were the first reported ILs to exhibit non-Newtonian viscosity behavior. ${ }^{23}$ Notably, differential scanning calorimetry, polarized optical microscopy, and temperature-programmed IR reflection absorption spectroscopy performed on a mixture of $10 \mathrm{wt} \% \mathrm{Ni}$ catalyst $\left[\mathrm{NiCl}_{2}\left(\mathrm{C}_{12} \mathrm{C}_{12} \mathrm{IM}\right)_{2}\right]$ in $\left[\mathrm{C}_{12} \mathrm{C}_{12} \mathrm{IM}\right]\left[\mathrm{BF}_{4}\right]$ demonstrated that this system retains an ionic liquid crystalline phase; even after immobilization on a porous silica-100 support. ${ }^{24}$ The 
catalytic organic reactions (e.g. olefin dimerization) were carried out at room temperature to prevent catalyst decomposition at higher temperature. Thus, it was necessary for the reaction media composed of ionic liquid crystals to have a liquid crystalline phase at room temperature. Therefore, we recently turned our attention to the synthesis and characterization of a series of ILs, namely $\left[\mathrm{C}_{12} \mathrm{C}_{12} \mathrm{IM}\right][\mathrm{A}]$ (where $\mathrm{A}=\mathrm{I}^{-}, \mathrm{I}_{3}{ }^{-}, \mathrm{I}_{5}{ }^{-}$, $\left.\left.\mathrm{N}(\mathrm{CN})_{2}{ }^{-}, \mathrm{C}(\mathrm{CN})_{3}{ }^{-}, \mathrm{B}(\mathrm{CN})_{4}{ }^{-}, \mathrm{SbF}_{6}{ }^{-}\right]\right)$. However, among these ILs, only the monoiodide salt $\left[\mathrm{C}_{12} \mathrm{C}_{12} \mathrm{IM}\right][\mathrm{I}]$ exhibits a liquid crystalline phase in the temperature range from 40.4 to $88.5^{\circ} \mathrm{C}^{25}$ The effect of the respective anion on the solid-state molecular structures of these materials (e.g. degree of ordering, orientation of the alkyl chains with respect to the cationic imidazolium moiety, formation of polar and non-polar domains in the solid state, etc.) was studied by single-crystal X-ray diffraction methods and discussed previously. ${ }^{25}$

Attempting to improve the selectivity of catalytic reactions by creating a pre-organized, well-ordered reaction environment (e.g. for olefin dimerization catalysis), we also studied the use of the newly synthesized ILCs, such as $\left[\mathrm{C}_{12} \mathrm{C}_{12} \mathrm{IM}\right]\left[\mathrm{BF}_{4}\right]$, in "Supported Ionic Liquid Phase" (SILP) catalysis. Due to the known thermal instability of self-activated catalysts, such as $\left[\left(\kappa^{2}-P, O-\right.\right.$ bis-diphenylphosphanylmonoxide) $\mathrm{Ni}\left(\eta^{3}\right.$-methallyl $\left.)\right]^{+},{ }^{26}$ catalytic reactions with these complexes have to be carried out at room temperature. One example is the dimerization of ethylene with Ni-based SILP-type catalysts based on $\left[\mathrm{C}_{2} \mathrm{MIM}\right][\mathrm{FAP}]$ (with FAP $=$ tris(pentafluoroethyl)trifluorophosphate anion). ${ }^{27}$ Therefore, we focused our subsequent research on finding conveniently tunable ionic liquid crystal solvents with liquid crystalline phases at room temperature.

Here, we report the synthesis and characterization of long alkyl chain substituted 1,3-dialkylimidazolium-based ionic liquids and ionic liquid crystals. The previously reported 1,3didodecylimidazolium salts were further modified by incorporating anions like $\left[\mathrm{PF}_{6}\right]^{-},[\mathrm{OTf}]^{-},\left[\mathrm{NTf}_{2}\right]^{-}$. In addition, the length of the even-numbered, symmetrically derivatized alkyl chains were varied from $\mathrm{C}_{10}$ to $\mathrm{C}_{18}$ for the $\left[\mathrm{BF}_{4}\right]^{-}$and $\left[\mathrm{ClO}_{4}\right]^{-}$imidazolium salts, in order to study the thermal behavior of these derivatives. The modification of the alkyl chain length at the functionalized cation was expected to result in an alteration of the melting point and in an increase of the viscosity and hydrophobicity of the liquids. ${ }^{28}$

\section{Result and discussion}

\section{Synthesis}

A series of new $\mathrm{C}_{12}$ alkyl chain derivatized imidazolium (IM) based ionic liquids, namely $\left[\mathrm{C}_{12} \mathrm{C}_{12} \mathrm{IM}\right][\mathrm{A}]$ with $\mathrm{A}=\mathrm{PF}_{6}{ }^{-}$, OTf ${ }^{-}$, or $\mathrm{NTf}_{2}{ }^{-}$, were prepared by ion exchange from $\left[\mathrm{C}_{12} \mathrm{C}_{12} \mathrm{IM}\right] \mathrm{Cl}$ and the corresponding ammonium or lithium salts. The 1,3dialkylimidazolium tetrafluoroborate $\left[\mathrm{C}_{n} \mathrm{C}_{n} \mathrm{IM}\right]\left[\mathrm{BF}_{4}\right]$ and the corresponding perchlorate salt $\left[\mathrm{C}_{n} \mathrm{C}_{n} \mathrm{IM}\right]\left[\mathrm{ClO}_{4}\right](n=10,14,16$, 18) were prepared analogously to the previously reported synthesis of $\left[\mathrm{C}_{12} \mathrm{C}_{12} \mathrm{IM}\right]\left[\mathrm{BF}_{4}\right]$ and $\left[\mathrm{C}_{12} \mathrm{C}_{12} \mathrm{IM}\right]\left[\mathrm{ClO}_{4}\right]$ salts (Scheme 1). ${ }^{23}$ Anion metathesis was carried out in organic solvents and precipitation of the produced $\mathrm{LiCl} / \mathrm{NH}_{4} \mathrm{Cl} / \mathrm{NaCl}$ from organic solvents allowed for convenient separation by

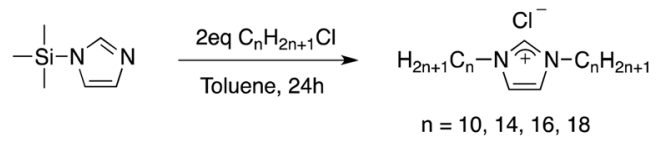

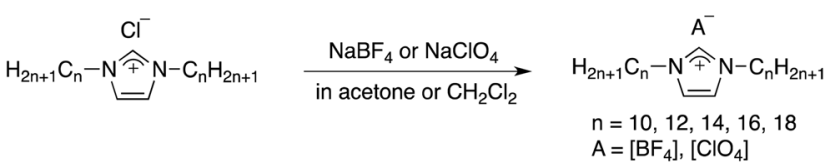

Scheme 1 Synthesis of the dialkylimidazolium tetrafluoroborate and perchlorate salts.

filtration. In addition, extraction of the ILs into $\mathrm{CH}_{2} \mathrm{Cl}_{2}$, and washing the solution with water, in which the ILs are insoluble, removed the remaining trace salt impurities. The imidazolium chloride starting materials were synthesized by alkylation of $N$-trimethylsilylimidazole with alkylchloride according to literature procedures. ${ }^{29}$ A straightforward procedure for the preparation of symmetrical 1,3-dialkylimidazolium salts was used: employing the highly reactive silylated imidazole and two equiv. of alkylhalide lead to quantitative quaternization and formation of trimethylsilyl chloride and bromide. Notably, the product ILs are solid compounds at RT, facilitating purification via recrystallization. In order to proof the purity of the bulk sample, all compounds were characterized by CHN elemental analyses as well as ${ }^{1} \mathrm{H}$ and ${ }^{13} \mathrm{C}$ NMR spectroscopy (see ESI $\dagger$ ). All final products were dried in vacuo at $70{ }^{\circ} \mathrm{C}$ for 24 hours to remove traces of water. As expected, the solubility in polar organic solvents decreases with increasing chain length of the derivatized ILs.

\section{Thermal behavior}

The thermal properties of the newly synthesized compounds were studied by differential scanning calorimetry (DSC) and polarized optical microscopy (POM). After the initial heating and cooling cycle the observed transition temperatures were reproducible and constant for all subsequent cycles. Accordingly, the transition temperatures and enthalpies of the compounds are reported, starting from the second heating cycle of the DSC studies. The key results are summarized in Table 1 and 2.

Table 1 Phase-transition temperatures (in ${ }^{\circ} \mathrm{C}$ ) and enthalpies of transition $\left(\Delta H\right.$ in $\left.\mathrm{kJ} \mathrm{mol}^{-1}\right)$ of $\left[\mathrm{C}_{12} \mathrm{C}_{12} \mathrm{IM}\right][\mathrm{A}]\left(\mathrm{A}=\mathrm{PF}_{6}{ }^{-}, \mathrm{OTf}^{-}, \mathrm{NTf}_{2}{ }^{-}\right)$ determined by DSC (onset data, second heating cycle, $\mathrm{Cr}=$ crystalline phase, Iso = isotropic phase)
Compound
Phase transition behavior
$\left[\mathrm{C}_{12} \mathrm{C}_{12} \mathrm{IM}\right]\left[\mathrm{PF}_{6}\right]$

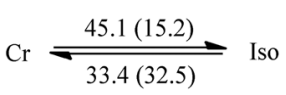
$\left[\mathrm{C}_{12} \mathrm{C}_{12} \mathrm{IM}\right][\mathrm{OTf}]$

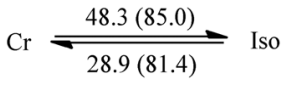
$\left[\mathrm{C}_{12} \mathrm{C}_{12} \mathrm{IM}\right]\left[\mathrm{NTf}_{2}\right]$
$\mathrm{Cr} \frac{42.1(109.4)}{6.9(83.5)}$ Iso 
Table 2 Phase-transition temperatures (in ${ }^{\circ} \mathrm{C}$ ) and enthalpies of transition $\left(\Delta H\right.$ in kJ mol $\left.{ }^{-1}\right)$ of compounds $\left[C_{n} C_{n} \mid \mathrm{M}\right][A]\left(n=10,12,{ }^{23} 14,16,18 ; A\right.$ $=\mathrm{BF}_{4}{ }^{-}$and $\mathrm{ClO}_{4}^{-}$) determined by DSC (onset data, second heating cycle, $\mathrm{Cr}=$ crystalline phase, $\mathrm{SmA}=$ smectic-A phase, Iso $=$ isotropic phase)

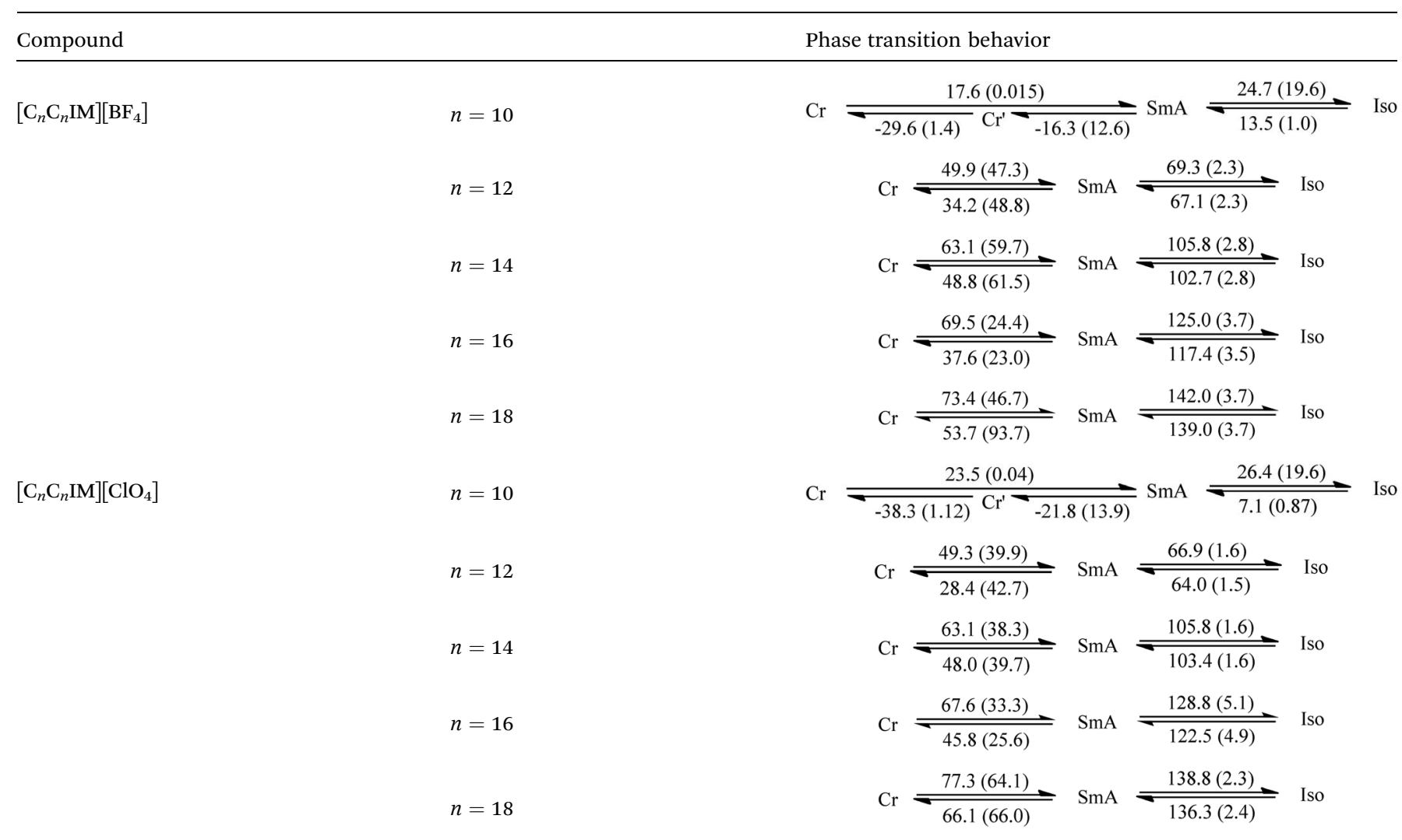

The DSC thermograms of $\left[\mathrm{C}_{12} \mathrm{C}_{12} \mathrm{IM}\right][\mathrm{A}]\left(\mathrm{A}=\mathrm{PF}_{6}{ }^{-}, \mathrm{OTf}^{-}\right.$, $\mathrm{NTf}_{2}{ }^{-}$) clearly confirm all three compounds to be ionic liquids with melting points ranging from $40{ }^{\circ} \mathrm{C}$ to approx. $50{ }^{\circ} \mathrm{C}$ (Table 1). However, these materials show no phase transition that could be attributed to a mesophase formation of a liquid crystalline material. Thus, among the very large variety of $\left[\mathrm{C}_{12} \mathrm{C}_{12} \mathrm{IM}\right][\mathrm{A}]$-based ionic liquids reported here and previously ${ }^{\mathbf{2 3 2 5}}$ with the anions $\left[\mathrm{BF}_{4}\right]^{-},\left[\mathrm{ClO}_{4}\right]^{-}, \mathrm{I}^{-},\left[\mathrm{I}_{3}\right]^{-},\left[\mathrm{I}_{5}\right]^{-}$, $\left[\mathrm{N}(\mathrm{CN})_{2}\right]^{-},\left[\mathrm{C}(\mathrm{CN})_{3}\right]^{-},\left[\mathrm{B}(\mathrm{CN})_{4}\right]^{-},\left[\mathrm{SbF}_{6}\right]^{-},\left[\mathrm{PF}_{6}\right]^{-},[\mathrm{OTf}]^{-}$, and $\left[\mathrm{NTf}_{2}\right]^{-}$, only the salts with $\left[\mathrm{BF}_{4}\right]^{-},\left[\mathrm{ClO}_{4}\right]^{-}$, and $\mathrm{I}^{-}$counter-ions show a liquid crystalline phase. For a given cation with different anions, the melting point is increasing in the order $\left[\mathrm{I}_{5}\right]^{-}<$ $\left[\mathrm{SbF}_{6}\right]^{-}<\left[\mathrm{NTf}_{2}\right]^{-}<\left[\mathrm{N}(\mathrm{CN})_{2}\right]^{-} \approx\left[\mathrm{C}(\mathrm{CN})_{3}\right]^{-}<\left[\mathrm{PF}_{6}\right]^{-} \approx\left[\mathrm{I}_{3}\right]^{-}<$ $[\mathrm{OTf}]^{-} \approx\left[\mathrm{B}(\mathrm{CN})_{4}\right]^{-}$. These differences in melting point originate from a complex interplay of coulombic, H-bonding, and van-der-Waals interactions within the respective IL components.

Since liquid crystalline phases could not be observed in the ILs listed in Table 1, only the double alkyl chain substituted imidazolium-based IL materials $\left[\mathrm{C}_{n} \mathrm{C}_{n} \mathrm{IM}\right]\left[\mathrm{BF}_{4}\right]$ and $\left[\mathrm{C}_{n} \mathrm{C}_{n} \mathrm{IM}\right]$ $\left[\mathrm{ClO}_{4}\right]$, with varying alkyl chain lengths $n=10,14,16$, and 18 were studied further. The thermal properties of these compounds are shown in Table 2 . All $\left[\mathrm{BF}_{4}\right]^{-}$and $\left[\mathrm{ClO}_{4}\right]^{-}$salts exhibit liquid crystalline behavior. For reference and comparison, we included the previously reported $\left[\mathrm{C}_{12} \mathrm{C}_{12} \mathrm{IM}\right]\left[\mathrm{BF}_{4}\right]$ and $\left[\mathrm{C}_{12} \mathrm{C}_{12} \mathrm{IM}\right]\left[\mathrm{ClO}_{4}\right]$ salts in Table 2 . From the DSC thermograms of the tetrafluoroborate series it is evident that these compounds show relatively low transition temperatures from solid to mesophase: 17.6, 49.9, 63.1, 69.5, and $73.4{ }^{\circ} \mathrm{C}$, respectively, and the clearing temperature increases rapidly with chain length: from $24.7,69.3,105.8,125.0$ to $142.0^{\circ} \mathrm{C}$. For the perchlorate series, the melting point is quite similar to the $\left[\mathrm{BF}_{4}\right]^{-}$salts. The solid to mesophase transition temperature, however, is significantly different and was determined to be 23.5, 49.3, 63.1, 67.6, and $77.3{ }^{\circ} \mathrm{C}$, respectively. The clearing temperature increases with chain length from 26.4, 66.9, 105.8, and $128.8-138.8{ }^{\circ} \mathrm{C}$.

In Fig. 1, the phase transitions of the mesogenic imidazolium $\left[\mathrm{BF}_{4}\right]^{-}$and $\left[\mathrm{ClO}_{4}\right]^{-}$salts with different chain lengths are summarized. There is a notable increase in both melting and clearing points with increasing chain length in both salt series. The liquid crystalline mesophase range (temperature window) of both series increases with increasing alkyl chain length, which is mainly due to the stronger van-der-Waals interactions among the longer alkyl substituents of the cation. In addition, it is interesting to note that Rohini et al. report a series of 1,3dialkylimidazolium chloride and bromide salts with significantly higher clearing temperatures, and thus larger mesophase ranges, than observed for the here reported $\left[\mathrm{BF}_{4}\right]^{-}$and $\left[\mathrm{ClO}_{4}\right]^{-}$ salts. This may indicates that the anion, and thus electrostatic interactions, plays significant role for the formation of mesophases. ${ }^{30}$ 


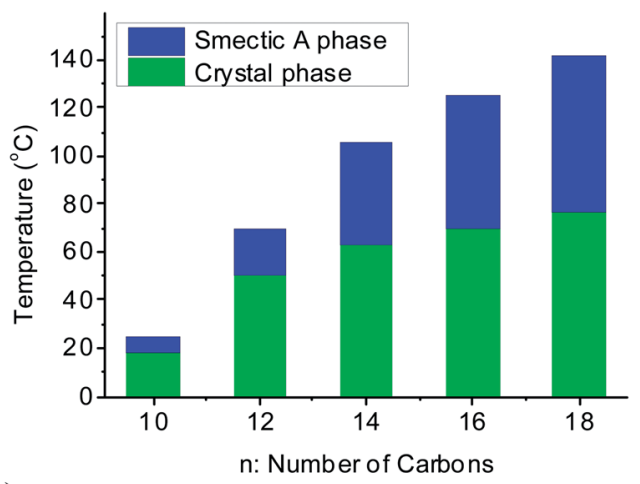

a)

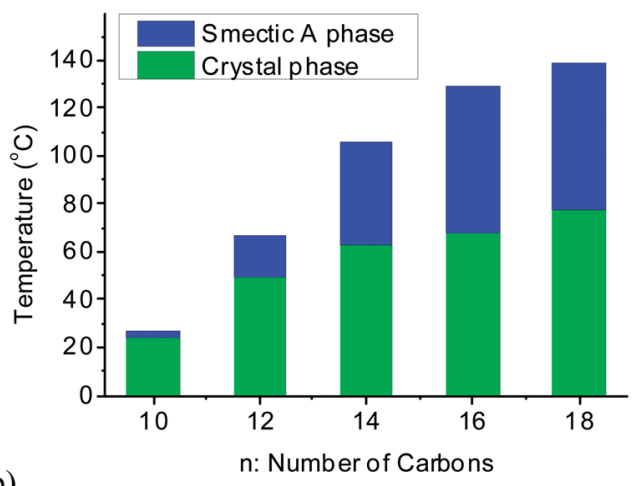

Fig. 1 Mesophase temperature ranges of (a) $\left.\left[\mathrm{C}_{n} \mathrm{C}_{n} \mid \mathrm{M}_{[}\right] \mathrm{BF}_{4}\right]$ and (b) $\left[\mathrm{C}_{n} \mathrm{C}_{n} \mid \mathrm{M}\right]\left[\mathrm{ClO}_{4}\right]$ salts (with $n=10,12,14,16$, and 18).

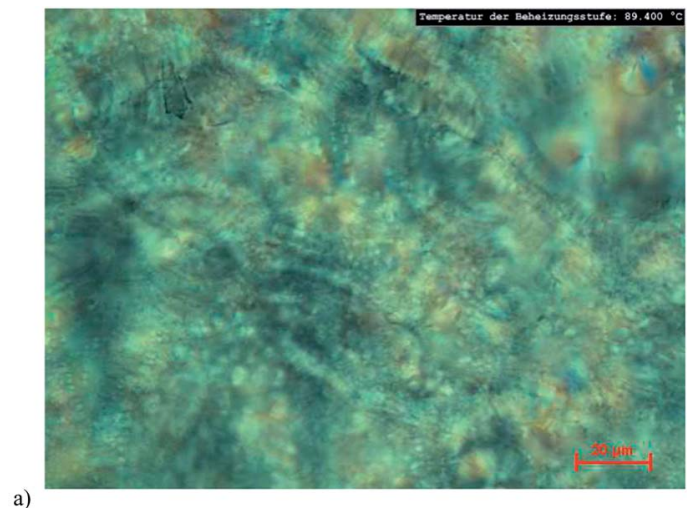

a)

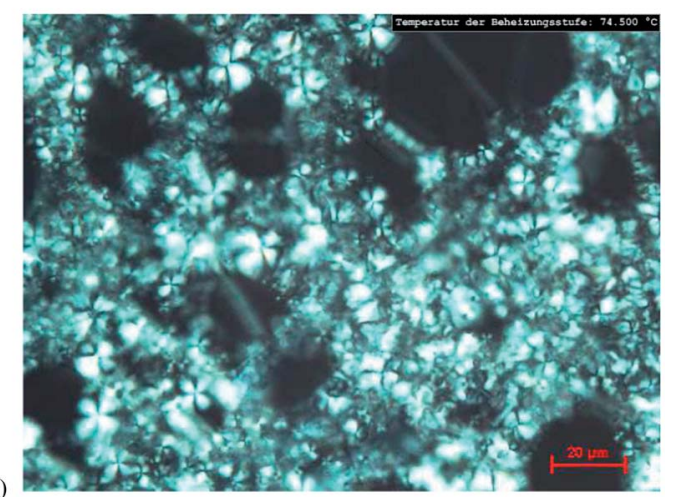

Fig. 2 POM images for (a) $\left[\mathrm{C}_{16} \mathrm{C}_{16} \mid \mathrm{M}\right]\left[\mathrm{BF}_{4}\right]$ at $90.0{ }^{\circ} \mathrm{C}$ and (b) $\left[\mathrm{C}_{16} \mathrm{C}_{16} \mid \mathrm{M}\right]\left[\mathrm{ClO}_{4}\right]$ at $74.5^{\circ} \mathrm{C}$.
In order to monitor the ILs' thermal stability, the $\left[\mathrm{BF}_{4}\right]^{-}$salts were examined by thermogravimetric analysis (TGA). TGA thermograms of the tetrafluoroborate salts, recorded at a rate of $10 \mathrm{~K} \mathrm{~min}^{-1}$, show that the decomposition temperatures for $\left[\mathrm{C}_{10} \mathrm{C}_{10} \mathrm{IM}\right]\left[\mathrm{BF}_{4}\right],\left[\mathrm{C}_{12} \mathrm{C}_{12} \mathrm{IM}\right]\left[\mathrm{BF}_{4}\right],\left[\mathrm{C}_{14} \mathrm{C}_{14} \mathrm{IM}\right]\left[\mathrm{BF}_{4}\right], \quad\left[\mathrm{C}_{16} \mathrm{C}_{16} \mathrm{IM}\right]$ $\left[\mathrm{BF}_{4}\right]$, and $\left[\mathrm{C}_{18} \mathrm{C}_{18} \mathrm{IM}\right]\left[\mathrm{BF}_{4}\right]$ are all above $350{ }^{\circ} \mathrm{C}$.

To verify the aforementioned mesophases, polarized optical microscopy (POM) studies were performed on all of the $\left[\mathrm{BF}_{4}\right]^{-}$ and $\left[\mathrm{ClO}_{4}\right]^{-}$salts that exhibit liquid crystalline characteristics. These compounds were heated to form an isotropic melt and then cooled at a rate of $5 \mathrm{~K} \mathrm{~min}^{-1}$ while being examined by crossed polarizers. In this case, the transition to the liquid crystalline phases could be followed. The observed focal coinic texture points to smectic-A phases. Birefringent textures were observed for the ILCs that exhibit a mesophase as determined by DSC (Fig. 2 and ESI $\dagger$ ). During cooling, POM images for $\left[\mathrm{C}_{10} \mathrm{C}_{10} \mathrm{IM}\right]\left[\mathrm{BF}_{4}\right]$ show a liquid crystalline phase below $12{ }^{\circ} \mathrm{C}$; and during heating in a narrow temperature range around $28^{\circ} \mathrm{C}$. It is interesting to note that, during the second cooling cycle, when cooling to room temperature, this sample re-establishes its liquid crystalline phase not immediately but only after a few minutes (Fig. 3). This is probably due to slow dynamics in the reorganization of this IL, such as cooperative linking of crystallization and complex conformation change in dense fields. $^{31,32}$

\section{Viscosity of $\left[\mathrm{C}_{16} \mathrm{C}_{16} \mathrm{IM}\right]\left[\mathrm{BF}_{4}\right]$ and $\left[\mathrm{C}_{16} \mathrm{C}_{16} \mathrm{IM}\right]\left[\mathrm{ClO}_{4}\right]$}

In previous studies, we observed - and reported for the first time - that the ILCs $\left[\mathrm{C}_{12} \mathrm{C}_{12} \mathrm{IM}\right]\left[\mathrm{BF}_{4}\right]$ and $\left[\mathrm{C}_{12} \mathrm{C}_{12} \mathrm{IM}\right]\left[\mathrm{ClO}_{4}\right]$ exhibit strong non-Newtonian viscosity behavior (shear-thinning fluid). ${ }^{23}$ In anticipation that other ILCs may also display non-Newtonian viscosity, we investigated the newly synthesized ILCs. Fig. 4 and 5 display the respective viscosity shear rate diagrams for $\left[\mathrm{C}_{16} \mathrm{C}_{16} \mathrm{IM}\right]\left[\mathrm{BF}_{4}\right]$ and the corresponding $\left[\mathrm{ClO}_{4}\right]^{-}$ salt. The viscosity of both ILCs is dependent on the shear rate applied to the sample during the mesophase and the viscosity decreases drastically following an increase of the shear rate. For example, the viscosity of $\left[\mathrm{C}_{16} \mathrm{C}_{16} \mathrm{IM}\right]\left[\mathrm{BF}_{4}\right]$ abruptly decreases from 6.51 to $0.727 \mathrm{~Pa} s$ when the shear rate increases from 10 to $500 \mathrm{~s}^{-1}$ at $100{ }^{\circ} \mathrm{C}$. In fact, both new compounds are non-Newtonian fluids during their mesophases. In the liquid phase, the

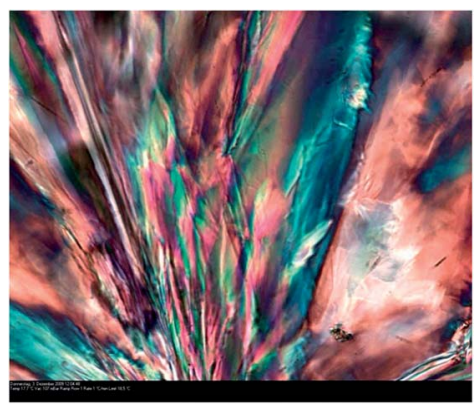

Fig. 3 POM image of $\left[\mathrm{C}_{10} \mathrm{C}_{10} \mathrm{IM}\right]\left[\mathrm{BF}_{4}\right]$ at $17.7^{\circ} \mathrm{C}(200 \times$ magnification). Liquid crystalline phase re-establishes after several minutes when cooling to $17.7^{\circ} \mathrm{C}$. 
ILs behave like Newton fluids. ${ }^{28}$ Increasing the shear rate, the viscosity remains constant. At higher temperatures a decrease in the viscosity is observed. This result is in good agreement with those we previously reported. ${ }^{23}$ Due to these results, we speculate that all other ILCs in this report are also non-Newtonian fluids and hypothesize that non-Newtonian viscosity behavior is a typical property of ILCs with long alkyl chains, $c f$., $\mathrm{C}_{12}-\mathrm{C}_{18}$.

\section{Mixtures of ILCs}

In order to optimize and tailor the ILCs properties, e.g., the mesophase temperature window for synthetic applications, three different mixtures of the compounds $\left[\mathrm{C}_{10} \mathrm{C}_{10} \mathrm{IM}\right]\left[\mathrm{BF}_{4}\right]$ and $\left[\mathrm{C}_{12} \mathrm{C}_{12} \mathrm{IM}\right]\left[\mathrm{BF}_{4}\right]^{23}$ with molar ratios of $1: 3$ (I), $1: 1$ (II), and $3: 1$ (III) were examined and their thermal properties were investigated by DSC. Interestingly, and entirely absent in each of the neat materials, the DSC measurements (Table 3) show a wide liquid crystalline phase for mixture $\mathrm{I}$ between $38.7^{\circ} \mathrm{C}$ and 55.7 ${ }^{\circ} \mathrm{C}$ during heating, and between $53.0{ }^{\circ} \mathrm{C}$ and $8.5{ }^{\circ} \mathrm{C}$ during cooling, which is in an appropriate temperature range for many transition metal catalyzed reactions (Fig. 6). Notably, the equimolar and inverse $3: 1$ mixtures II and III, however, exhibit a mesophase only during cooling.

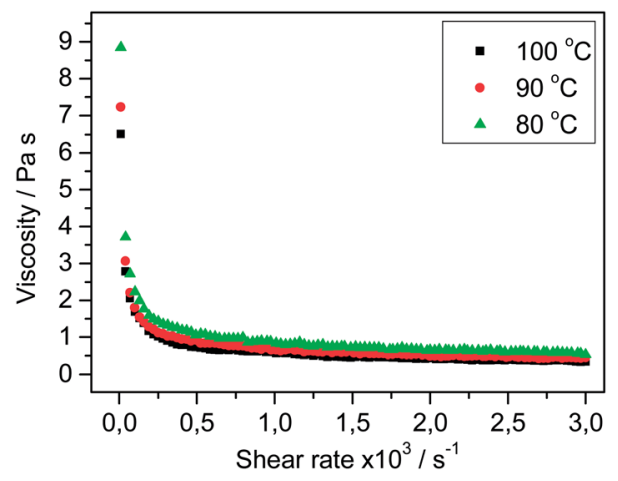

Fig. 4 Viscosity vs. shear rate for $\left[C_{16} C_{16} \mid M\right]\left[B F_{4}\right]$ in the liquid crystalline temperature range $\left(80-100{ }^{\circ} \mathrm{C}\right)$.

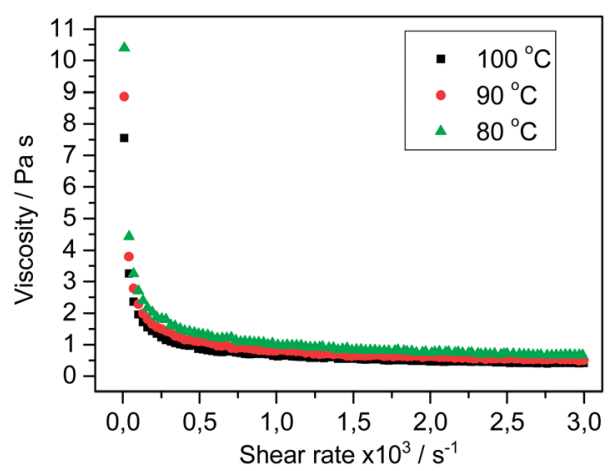

Fig. 5 Viscosity vs. shear rate for $\left[\mathrm{C}_{16} \mathrm{C}_{16} \mid \mathrm{M}\right]\left[\mathrm{ClO}_{4}\right]$ in the liquid crystalline temperature range $\left(80-100^{\circ} \mathrm{C}\right)$.
Table 3 Phase-transition temperatures (in ${ }^{\circ} \mathrm{C}$ ) of $\left[\mathrm{C}_{10} \mathrm{C}_{10} \mathrm{IM}\right]\left[\mathrm{BF}_{4}\right]$ and $\left[\mathrm{C}_{12} \mathrm{C}_{12} \mathrm{IM}\right]\left[\mathrm{BF}_{4}\right]$ mixtures with molar ratios of $1: 3$ (I), $1: 1$ (II), $3: 1$ (III) as determined by DSC (onset data, second heating cycle, $\mathrm{Cr}=$ crystalline phase, $\mathrm{SmA}=$ smectic-A phase, Iso = isotropic phase)

\begin{tabular}{|c|c|c|c|c|}
\hline Compounds & $\begin{array}{l}\text { Cr-SmA } \\
\text { upon heating }\end{array}$ & $\begin{array}{l}\text { SmA-Iso } \\
\text { upon heating }\end{array}$ & $\begin{array}{l}\text { Iso-SmA } \\
\text { upon cooling }\end{array}$ & $\begin{array}{l}\text { SmA-Cr } \\
\text { upon cooling }\end{array}$ \\
\hline $\begin{array}{l}\mathrm{C}_{10}: \mathrm{C}_{12}= \\
1: 3(\mathrm{I})\end{array}$ & 38.7 & 55.7 & 53.0 & 8.5 \\
\hline $\begin{array}{l}\mathrm{C}_{10}: \mathrm{C}_{12}= \\
1: 1(\text { III })\end{array}$ & 42.1 & & 38.5 & -14.0 \\
\hline $\begin{array}{l}\mathrm{C}_{10}: \mathrm{C}_{12}= \\
3: 1 \text { (III) }\end{array}$ & 35.3 & & 25.7 & -24.6 \\
\hline
\end{tabular}

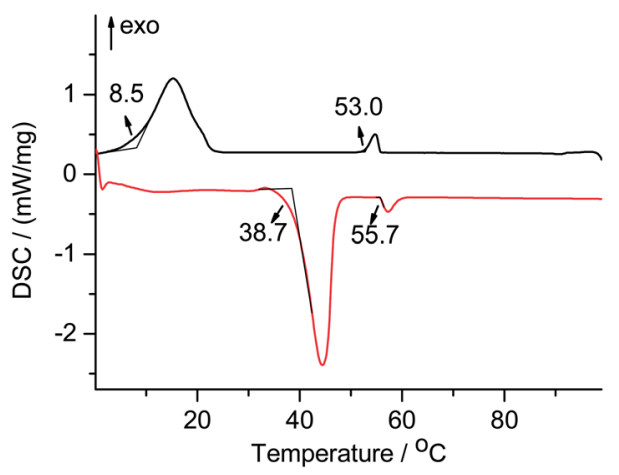

Fig. 6 DSC of a mixed $\left[\mathrm{C}_{10} \mathrm{C}_{10} \mathrm{IM}\right]\left[\mathrm{BF}_{4}\right]$ and $\left[\mathrm{C}_{12} \mathrm{C}_{12} \mid \mathrm{M}\right]\left[\mathrm{BF} \mathrm{F}_{4}\right]$ in a molar ratio of $1: 3,2^{\text {nd }}$ heating cycle (bottom), $2^{\text {nd }}$ cooling cycle (top).

\section{Conclusion}

We have synthesized a new series of 1,3-dialkylimidazolium salts $\left[\mathrm{C}_{12} \mathrm{C}_{12} \mathrm{IM}\right][\mathrm{A}]$ (with $\mathrm{A}=\left[\mathrm{PF}_{6}{ }^{-}\right],\left[\mathrm{OTf}^{-}\right]$, and $\left[\mathrm{NTf}_{2}{ }^{-}\right]$) and $\left[\mathrm{C}_{n} \mathrm{C}_{n} \mathrm{IM}\right][\mathrm{A}]$ (with $n=10,14,16,18$; and $\mathrm{A}=\mathrm{BF}_{4}{ }^{-}, \mathrm{ClO}_{4}{ }^{-}$). Three of these 1,3-didodecylimidazolium salts are ILs at room temperature, whereas the eight dialkylimidazolium tetrafluoroborate and perchlorate salts exhibit liquid crystalline phases over an adjustable and wide temperature range. Most notably, the mixture of $\left[\mathrm{C}_{10} \mathrm{C}_{10} \mathrm{IM}\right]\left[\mathrm{BF}_{4}\right]$ and $\left[\mathrm{C}_{12} \mathrm{C}_{12} \mathrm{IM}\right]\left[\mathrm{BF}_{4}\right]$ with a molar ratio of $1: 3$ shows a liquid crystalline phase at room temperature, rendering this mixture a suitable solvent for synthetic applications with the possibility of improved selectivity properties due to pre-organization of the reaction medium. Examination of the viscosity of $\left[\mathrm{C}_{16} \mathrm{C}_{16} \mathrm{IM}\right]\left[\mathrm{BF}_{4}\right]$ and $\left[\mathrm{C}_{16} \mathrm{C}_{16} \mathrm{IM}\right]\left[\mathrm{ClO}_{4}\right]$ as a function of shear rate revealed non-Newtonian viscosity behavior for both ionic liquids. From our results we also conclude that non-Newtonian viscosity behavior is likely a typical property of ILCs with long alkyl chains.

\section{Acknowledgements}

The authors gratefully acknowledge funding of the German Research Council (DFG) which, within the framework of its "Excellence Initiative", supports the Cluster of Excellence "Engineering of Advanced Materials" (https://www.eam.uni- 
erlangen.de) at the University of Erlangen-Nuremberg. We thank Dr Susanne Hibler and Dr Henning Gieseler (Division of Pharmaceutics, Freeze Drying Focus Group, FAU) for assistance with the POM and the recording of some POM images.

\section{References}

1 (a) N. V. Plechkova and K. R. Seddon, Chem. Soc. Rev., 2008, 1, 123; (b) S. Werner, M. Haumann and P. Wasserscheid, Annu. Rev. Chem. Biomol. Eng., 2010, 1, 203.

2 K. Binnemans, Chem. Rev., 2005, 11, 4148.

3 (a) Y. Bai, Y. Cao, J. Zhang, M. Wang, R. Li, P. Wang, S. M. Zakeeruddin and M. Gratzel, Nat. Mater., 2008, 8, 626; (b) Y. Cao, J. Zhang, Y. Bai, R. Li, S. M. Zakeeruddin, M. Grätzel and P. Wang, J. Phys. Chem. C, 2008, 35, 13775; (c) R. D. Costa, F. Werner, X. Wang, P. Grönninger, S. Feihl, F. T. U. Kohler, P. Wasserscheid, S. Hibler, R. Beranek, K. Meyer and D. M. Guldi, Adv. Energy Mater., 2013, 5, 657; (d) S. M. Zakeeruddin and M. Grätzel, Adv. Funct. Mater., 2009, 14, 2187.

4 K. V. Axenov and S. Laschat, Materials, 2011, 1, 206.

5 (a) C. K. Lee, J. C. C. Chen, K. M. Lee, C. W. Liu and I. J. B. Lin, Chem. Mater., 1999, 5, 1237; (b) C. K. Lee, K. M. Lee and I. J. B. Lin, Organometallics, 2001, 1, 10; (c) K. M. Lee, H. M. J. Wang and I. J. B. Lin, J. Chem. Soc., Dalton Trans., 2002, 14, 2852; (d) H. M. J. Wang and I. J. B. Lin, Organometallics, 1998, 5, 972.

6 (a) V. César, S. Bellemin-Laponnaz and L. H. Gade, Organometallics, 2002, 24, 5204; (b) R. R. Deshmukh, R. Rajagopal and K. V. Srinivasan, Chem. Commun., 2001, 1544; (c) J. C. Garrison, R. S. Simons, J. M. Talley, C. Wesdemiotis, C. A. Tessier and W. J. Youngs, Organometallics, 2001, 7, 1276; (d) D. Sémeril, C. Bruneau and P. H. Dixneuf, Adv. Synth. Catal., 2002, 6-7, 585; (e) A. a. D. Tulloch, A. A. Danopoulos, S. Winston, S. Kleinhenz and G. Eastham, J. Chem. Soc., Dalton Trans., 2000, 24, 4499; (f) J.-C. Xiao, B. Twamley and J. N. M. Shreeve, Org. Lett., 2004, 21, 3845.

7 (a) A. E. Bradley, C. Hardacre, J. D. Holbrey, S. Johnston, S. E. J. Mcmath and M. Nieuwenhuyzen, Chem. Mater., 2002, 2, 629; (b) J. D. Holbrey and K. R. Seddon, J. Chem. Soc., Dalton Trans., 1999, 13, 2133; (c) J. De Roche, C. M. Gordon, C. T. Imrie, M. D. Ingram, A. R. Kennedy, F. Lo Celso and A. Triolo, Chem. Mater., 2003, 16, 3089; (d) A. Downard, M. J. Earle, C. Hardacre, S. E. J. Mcmath, M. Nieuwenhuyzen, S. J. Teat, 2003, 1, 43; (e) J. Dupont and P. a. Z. Suarez, Phys. Chem. Chem. Phys., 2006, 21, 2441; (f) D. M. Fox, W. H. Awad, J. W. Gilman, P. H. Maupin, H. C. De Long and P. C. Trulove, Green Chem., 2003, 6, 724; (g) K. Goossens, P. Nockemann, K. Driesen, B. Goderis, C. Görller-Walrand, K. Van Hecke, L. Van Meervelt, E. Pouzet, K. Binnemans and T. Cardinaels, Chem. Mater., 2007, 1, 157.
8 C. K. Lee, H. H. Peng and I. J. B. Lin, Chem. Mater., 2004, 3, 530.

9 K. Ming Lee, C. Kuan Lee and I. J. B. Lin, Chem. Commun., $1997,899$.

10 J. Y. Z. Chiou, J. N. Chen, J. S. Lei and I. J. B. Lin, J. Mater. Chem., 2006, 29, 2972.

11 P. H. J. Kouwer and T. M. Swager, J. Am. Chem. Soc., 2007, 45, 14042.

12 A. A. Fernandez, L. T. De Haan and P. H. J. Kouwer, J. Mater. Chem. A, 2013, 2, 354.

13 C. K. Lee, H. W. Huang and I. J. B. Lin, Chem. Commun., 2000, 1911.

14 D. Ster, U. Baumeister, J. L. Chao, C. Tschierske and G. Israel, J. Mater. Chem., 2007, 32, 3393.

15 W. Dobbs, L. Douce, L. Allouche, A. Louati, F. Malbosc and R. Welter, New J. Chem., 2006, 4, 528.

16 M. Yoshio, T. Mukai, H. Ohno and T. Kato, J. Am. Chem. Soc., 2004, 4, 994.

17 M. Yoshio, T. Mukai, H. Ohno and T. Kato, Ionic Liquids IV, ACS Symposium Series, 2007, vol. 975, ch. 11, p. 161.

18 K.-M. Lee, Y.-T. Lee and I. J. B. Lin, J. Mater. Chem., 2003, 5, 1079.

19 K.-M. Lee, J. C. C. Chen, C.-J. Huang and I. J. B. Lin, CrystEngComm, 2009, 12, 2804.

20 S.-C. Luo, S. Sun, A. R. Deorukhkar, J.-T. Lu, A. Bhattacharyya and I. J. B. Lin, J. Mater. Chem., 2011, 6, 1866.

21 M. R. Schenkel, R. Shao, L. A. Robertson, B. R. Wiesenauer, N. A. Clark and D. L. Gin, Liq. Cryst., 2013, 8, 1067.

22 (a) Y. Ji, R. Shi, Y. Wang and G. Saielli, J. Phys. Chem. B, 2013, 4, 1104; (b) G. Saielli, G. A. Voth and Y. Wang, Soft Matter, 2013, 24, 5716.

23 X. Wang, F. W. Heinemann, M. Yang, B. U. Melcher, M. Fekete, A.-V. Mudring, P. Wasserscheid and K. Meyer, Chem. Commun., 2009, 7405.

24 X. Wang, M. Sobota, F. T. U. Kohler, B. Morain, B. U. Melcher, M. Laurin, P. Wasserscheid, J. Libuda and K. Meyer, J. Mater. Chem., 2012, 5, 1893.

25 X. Wang, C. S. Vogel, F. W. Heinemann, P. Wasserscheid and K. Meyer, Cryst. Growth Des., 2011, 5, 1974.

26 I. Brassat, U. Englert, W. Keim, D. P. Keitel, S. Killat, G.-P. Suranna and R. Wang, Inorg. Chim. Acta, 1998, 1-2, 150.

27 J. Scholz, V. Hager, X. Wang, F. T. U. Kohler, M. Sternberg, M. Haumann, N. Szesni, K. Meyer and P. Wasserscheid, ChemCatChem, 2014, 1, 162.

28 C. Chiappe and D. Pieraccini, J. Phys. Org. Chem., 2005, 4, 275. 29 K. J. Harlow, A. F. Hill and T. Welton, Synthesis, 1996, 697.

30 R. Rohini, C.-K. Lee, J.-T. Lu and I. J. B. Lin, J. Chin. Chem. Soc., 2013, 7, 745.

31 M. Imanari, K. Fujii, T. Endo, H. Seki, K.-I. Tozaki and K. Nishikawa, J. Phys. Chem. B, 2012, 13, 3991.

32 Z. Hu and C. J. Margulis, Acc. Chem. Res., 2007, 11, 1097. 